\title{
Multifaceted characterization of a Lemanea fluviatilis population (Batracho- spermales, Rhodophyta) from a glacial stream in the south-eastern Alps
}

\author{
Abdullah A. SABer ${ }^{1 *}$, Marco CAntonAti ${ }^{2}$, Morgan L. VIS ${ }^{3}$, Andrea AnEsI ${ }^{4} \&$ Graziano Guella $^{4,5}$
}

${ }^{1}$ Botany Department, Faculty of Science, Ain Shams University, Abbassia Square-11566, Cairo, Egypt;* Corresponding author e-mail: abdullah_elattar@sci.asu.edu.eg,tel.: +20 111289955 7, fax: +2 0226857769

${ }^{2}$ Museo delle Scienze - MUSE, Limnology and Phycology Section, Corso del Lavoro e della Scienza 3, I-38123 Trento, Italy.email: marco.cantonati@muse.it. Tel: +393209224755

${ }^{3}$ Department of Environmental and Plant Biology, Ohio University, Athens, OH 45701, USA; e-mail: vischia@ohio.edu,tel.: +1 740-593-1134

${ }^{4}$ Department of Physics, Bioorganic Chemistry Lab, University of Trento, Via Sommarive 14, 38123 Povo, Trento,Italy; e-mail: graziano.guella@unitn.it,andrea.anesi@unitn.it

${ }^{5}$ CNR, Institute of Biophysics, Trento, Via alla Cascata 56/C, 38123 Povo, Trento, Italy

\begin{abstract}
The aim of this study was a combined and multifaceted characterization (morphological, molecular, lipid, pigment, and ecological data) of a Lemanea (freshwater red alga) population from the south-eastern Alps, exploring its adaptive strategies to the montane habitat, (turbulent, very-cold glacial stream with extremely low-conductivity). Although the thalli were small (only up to $1 \mathrm{~cm}$ ), the morphology was within the current circumscription of Lemanea fluviatilis. The molecular data placed this population within a clade of specimens identified as L. fluviatilis and L. fucina. This L. fluviatilis population was determined to possess lipid classes, especially phosphatidylcholine and monogalactosyldiacylglycerol with high unsaturation index (UI) and long acyl chains, which are typical adaptations for maintaining adequate membrane fluidity and consequently all the metabolic processes associated to the plasma membrane. The carotenoids profile revealed that, besides $\alpha / \beta-$ carotene, there are significant amounts of zeaxanthin and lutein. This study further demonstrated that red algae are a rich source of important food web $\omega-3$ fatty acids and may play an important role in the diets of grazers. L. fluviatilis is reported from one of the highest elevations (2,170 m a.s.l.) known for the genus Lemanea and this species. This study confirms the presence of L. fluviatilis in a cold, unpolluted, turbulent stream and this type of stream may be its preferred habitat.
\end{abstract}

Key words: Lemanea fluviatilis, freshwater, red alga, glacial stream, pigment analysis, lipidomics, adaptive mechanisms

\section{INTRODUCTION}

Within the freshwater order Batrachospermales, there are four genera, Lemanea, Paralemanea, Psilosiphon and Petrohua, with a unique pseudoparenchymatous tubular gametophytic thallus construction (ENTwisLE et al. 2009). This thallus morphology appears to have evolved three times in this order with Lemanea and $\mathrm{Pa}$ ralemanea being sister taxa and both Psilosiphon and Petrohua being distantly related in other clades of the Batrachospermales phylogeny (VIs et al. 2007). The genus Lemanea is easily distinguished from these other three pseudoparenchymatous tubular genera by the following suite of characters: a central axis lacking internal cortical filaments, T- /or L-shaped ray cells closely abutting the outer cortex, and spermatangia present in discrete patches on the nodes (VIS \& SHEATH 1992). Lemanea appears to be widely distributed in boreal and temperate regions of North America (e.g., VIS \& SHEATH 1992), and in fast-flowing streams in Europe (e.g., Eloranta \& Kwandrans 2007; KuČERA et al. 2008; ElorANTA et al. 2011, 2016). It has been frequently reported from India, but appears to be localized to Manipur state (GANESAN et al. 2015). In addition, this genus has been infrequently reported from China (XIE et al. 2004). L. fluviatilis has been frequently reported from Europe, North America and India (VIS \& SHEATH 1992; Eloranta et al. 2011; Ganesan et al. 2015 and the references therein).

Lemanea is known from a wide range of stream habitats from lowlands to mountains in both North America and Europe (VIS \& ShEATH 1992; KuČERA 
et al. 2008). However, this genus appears to be more prevalent in cooler, faster flowing streams (SHEATH \& HambrooK 1990; Eloranta \& KwANDRANS 2007; KuČERA et al. 2008; ElORANTA et al. 2016). There is scatter data in the literature regarding stream chemistry including nutrients (SHEATH \& HAMBrooK 1990 and the references therein; VIS \& SHEATH 1992; CARMONA et al. 2011. In Austria, it is considered indicative of high-altitude streams with low nutrient content (PIPP \& RotT 1994; RotT et al. 1999). Likewise, Lemanea species have been incorporated as an indicator of low nutrient streams in other European countries (e.g., RотT \& SCHNEIDER 2014).

Previous research on Lemanea has covered a variety of applied and basic topics. There have been a few applied studies of Lemanea in India ranging from use as an herbal remedy, diabetes treatment and biofuel production (GANESAN et al. 2015 table 2 and the references therein). Much of the basic Lemanea research has focused on the systematics, biogeography and potential use in biomonitoring (HARDING \& WHITTON 1981; Vis \& Sheath 1992; Eloranta et al. 2011). There have been a few studies of the ecophysiology of this genus primarily relating temperature and current velocity to chlorophyll a, dry mass and carbon assimilation as measures of vigor and growth (THIRB \& BENSON-Evans 1982, 1984, 1985). To our knowledge, there have been no studies regarding the lipid content of this taxon and how this may relate to thermal niche. However, the effects of temperature on fatty acids composition patterns have been addressed by some studies on micro- (e.g., Fuschino et al. 2011; FLAIM et al. 2012; LEBLOND et al. 2015) and macroalgae (e.g., BECKER et al. 2010).

The primary goal of the present study was to characterize a high-mountain population of Lemanea from a glacial stream in the south-eastern Alps by means of a multifaceted approach (genetics, morphological, membrane lipid and pigment analyses, and ecology), and relating these to potential adaptive mechanisms of this taxon to its glacial-stream habitat.

\section{Materials ANd Methods}

Study site. The Lemanea specimens were sampled at an elevation of $2170 \mathrm{~m}$ a.s.1., in the south-eastern Alps (Chiese stream at Levade, in the upper part of the Fumo Valley in the Adamello batholith, $46^{\circ} 07^{\prime} 23^{\prime \prime} \mathrm{N}, 10^{\circ} 33^{\prime} 54^{\prime \prime} \mathrm{E}$ ), in a glacier-fed, turbid and turbulent, well-oxygenated and cold $\left(5.86{ }^{\circ} \mathrm{C}\right.$, August $28^{\text {th }} 2014$ noon) stream. This stream flows over holocrystalline bedrock in the Adamello-Brenta Nature Park (Figs 1a-c).

Hydrochemical characterization. Water sampling was conducted using polyethylene bottles, which had previously been cleaned with ultrapure water and superpure nitric acid $(1 \%)$. Water temperature, $\mathrm{pH}$, and specific conductivity were assessed in the field using a HYDROLAB H20 multiprobe datasonde. Detailed hydrochemical characteristics of the stream including major ions, nutrients, trace elements and metals were investigated following standard procedures and methods (APHA 2000). Metals were analyzed by means of ICP-OES (Optima 5300 Perkin Elmer Corp.). The ions, $\mathrm{Na}^{+}$, $\mathrm{Ca}^{2+}, \mathrm{Mg}^{2+}, \mathrm{Cl}^{-}$and $\mathrm{SO}_{4}{ }^{2-}$ were measured using ionic chromatography (ICS 1500 Dionex Corp.). The nutrients $\left(\mathrm{N}-\mathrm{NO}_{3}^{-}\right.$, $\mathrm{N}-\mathrm{NH}_{4}^{+}, \mathrm{TN}, \mathrm{TP}$ and SRP) were by molecular absorption spectrometry and silicates as $\mathrm{SiO}_{2}$ by the molybdosilicate method (APHA 2000; CANTONATI et al. 2011).

Sampled algal materials. A stream reach about $20 \mathrm{~m}$ in length was inspected with an aquascope to identify the most suitable sampling points and to gain some information on the distribution of the species. Specimens included in this study were collected from rocks using forceps and placed in 100$\mathrm{ml}$ sterile clean polyethylene (PET) bottles for transport. The specimens were transported on ice to the laboratory for further studies. In the lab, the specimens were cleaned using distilled water to remove epiphytes and debris. This step was verified by microscopic examination. Subsequently, the specimens were divided into four portions. The first portion was dried in silica desiccant for DNA extraction, the second portion was fixed in $4 \%(\mathrm{v} / \mathrm{v})$ formaldehyde solution for morphological identification, the third portion that was wellcleaned was immediately used for lipidomics and bioorganic screening, and the fourth portion was stored as a voucher specimen in the Museo delle Scienze-MUSE, Trento, Italy, and the Phycology Unit NO. 341 in the Botany Department, Faculty of Science, Ain Shams University, Cairo, Egypt. For morphological identification and to visualize chromoplast autofluorescence, specimens were examined using both Zeiss Axioskop 2 microscope (Zeiss, Jena, Germany) in Italy and $\mathrm{BEL}^{\circledR}$ photonics biological microscope (Italy) in Egypt. Morphometric diagnostic features were measured and photographed using Axiocam and Canon Powershot G12 digital cameras. A total of 20 measurements were made for the taxonomically important morphometric features: thallus height, diameter without and with the spermatangial papillae, and the length of internodes. Specimens were morphologically identified using the relevant literature: VIS \& SHEATH (1992), Sheath \& Sherwood (2011) and Eloranta et al. (2011). Photomicrographs were arranged into plates using Adobe Photoshop (version CS 4, Adobe Systems Inc.).

Molecular data generation. For DNA extraction, thalli were ground in liquid $\mathrm{N}_{2}$ and extracted using Nucleospin Plant Genomic DNA kit (Macherey-Nagel) according to the manufacturer's protocol. The $r b c \mathrm{~L}$ gene was PCR amplified using the primer set (F160 \& rbcLR; VIS et al. 1998) and Extaq Polymerase system (Clontech Laboratories Inc.) in the thermocycler conditions described in KeIL et al. (2015). PCR product was purified using UltraClean PCR Clean-up DNA Purification Kit (Mo Bio Laboratories). The PCR product was sequenced using an ABI 3100 Genetic Analyzer (Applied Biosystems); the amplification primers and two internal primers (F650, R897.lem) were used to completely sequence the sense and anti-sense strand. Sequences were compiled in Sequencer 5.2.4 (GeneCodes Corp.). In order to explore the phylogenetic affinities of the new sequence, all $r b c \mathrm{~L}$ sequences available in GenBank for Lemanea (34) and Paralemanea (14) were obtained (GenBank accessed 25 March 2016). Two sequences were excluded AF029153 due to sequence quality and DQ523257 as it appeared to be a Batrachospermum and not a Lemanea sequence. Additional sequences of $\mathrm{Ba}$ - 

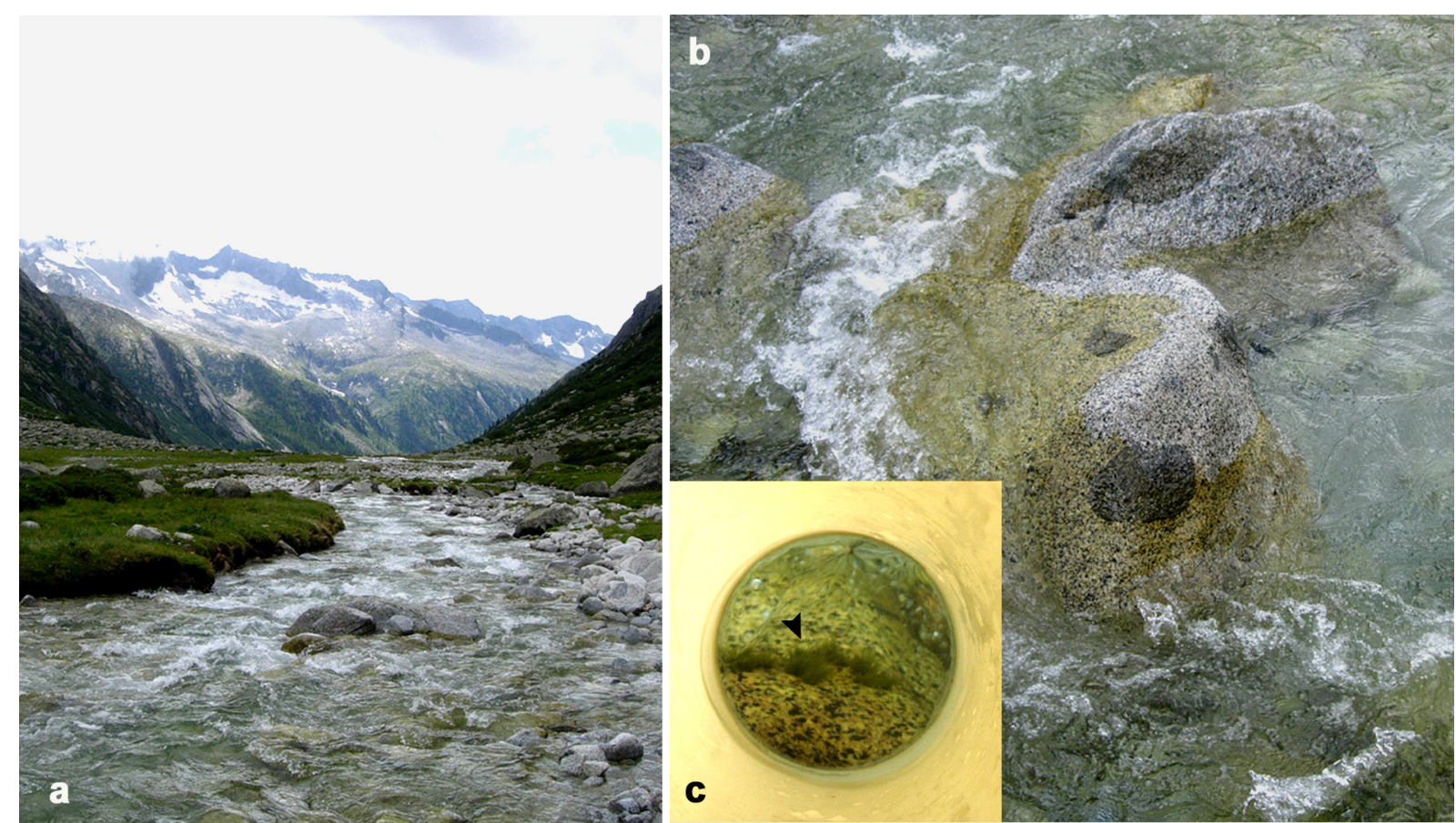

Fig. 1. Lemanea fluviatilis sampling site: (a) Chiese Stream at Levade in the Fumo Valley (Adamello-Brenta Nature Park, south-eastern Alps); (b) large boulders overflown by turbulent, swift, and cold water; (c) L. fluviatilis tufts on a boulder in the stream viewed using an aquascope.

trachospermum gelatinosum (L) DC, Sirodotia delicatula Skuja, S. huillensis (Welwitsch ex West \& G.S.West) Skuja, S. suecica Kylin and Tuomeya americana (Kützing) Papenfuss were utilized as outgroup sequences as these taxa have been shown to be most closely related to Lemanea and Paralemanea in previous studies of the Batrachospermales (VIS et al. 1998; ENTwISLE et al. 2009). If sequences were longer than $1282 \mathrm{bp}$, they were trimmed to that length before further analyses since most sequences were 1282 or shorter. The new sequence from this study was aligned with the previously published GenBank sequences using Muscle (EDGAR 2004) as implemented in Geneious Pro version 8.1.5 (Biomatters, Ltd., New Zealand, KeArse et al. 2012). The phylogenetic placement of the specimen was explored using Bayesian Inference (BI) Analysis in Mr.Bayes v.3.2.6 (RonQuist et al. 2012) and Maximum Likelihood (ML) Analysis in PhyML (Guindon \& Gascuel 2003) as implemented in Geneious Pro version 9.1.2. For both analyses, the general time reversible model was implemented with gamma for the BI and both gamma and invariant sites estimated by the program for ML. The BI analysis was run for 1,100,000 generations with a burn-in of 100,000. The ML analysis was run for 1000 generations using a parsimony-inferred starting tree with 1000 bootstrap replicates using a random starting tree. The new $r b c \mathrm{~L}$ sequence was submitted to GenBank (KU343187).

Lipid and pigment analyses. Total lipids were extracted by a slightly modified Folch method (FoLCH et al. 1957). Briefly, cell clusters were collected into $15 \mathrm{ml}$ glass tubes, re-suspended in $10 \mathrm{ml}$ of chloroform/methanol 2:1 (v/v), sonicated for $15 \mathrm{~min}$ in an ultrasonic bath (Sonorex Super, Bandelin electronics, Berlin, Germany), and centrifuged at $3000 \times g$ for $10 \mathrm{~min}$ at room temperature to separate the organic phase (bottom layer). For each cell pellet, the extraction procedure was repeated three times. All the organic phases were collected, filtered by using glass filters under vacuum, and reduced to dryness on a rotary evaporation (Büchi Labortechnik AG, Flawil, Switzerland) to obtain crude lipid extracts. Extracts were re-suspended in $300 \mu \mathrm{l}$ of methanol/chloroform 9:1 $(\mathrm{v} / \mathrm{v})$.

Crude lipid extracts were subjected to Reverse Phase Liquid Chromatography-Electrospray Ionization-Ion TrapMass Spectrometry analyses (RPLC-ESI-IT-MS). Under this chromatographic setup, lipid molecular species were separated primarily according to the hydrophobicity of their acyl chains. Details are reported in Guella et al. (2003). Hydrophilic Interaction LIquid Chromatography (HILIC) was also used to establish the membrane lipid class composition based on the different polarity of lipids head groups (ANESI \& Guella 2015).

Each lipid molecular species was quantified with respect to the total area of all lipid species belonging to the same class (e.g., relative quantification of $\mathrm{MGDG}_{\mathrm{x}}$ was performed with respect to total area of MGDG). The unsaturation index (UI) and the average chain length (ACL) were calculated for each lipid class, using the formulas

$\mathrm{UI}_{\text {class } y}=\Sigma$ (relative area lipid ${ }_{x} *$ double bond number of lipid $\left.{ }_{x}\right)$ and

$\mathrm{ACL}_{\text {class } y}=\Sigma$ (relative area lipid ${ }_{x} *$ acyl chain length of $\left.\operatorname{lipid}_{x}\right)$

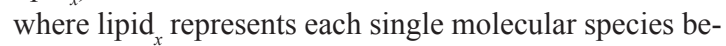
longing to the $y$ lipid class, respectively.

Pigments (chlorophylls and carotenoids) were simultaneously analyzed in the same chromatographic conditions through a Photo-Diode-Array detector (PDA) operating at $470 \mathrm{~nm}$ (carotenoids) and $660 \mathrm{~nm}$ (chlorophylls). Chromatographic peaks were identified by comparing retention times and online spectra (UV-Vis and positive and negative-ion ESI-MS spectra) against known standards (Frassanito et al. 2005). 


\section{Results}

\section{Ecological features}

The Lemanea population was thriving on the downstream edge of large boulders overflown by swift currents $\left(>1 \mathrm{~m} \cdot \mathrm{s}^{-1}\right)$. The thalli were in tufts or lawns on the boulders. In the stream reach examined the species colonized larger boulders in strong currents.

Stream chemistry including the primary ions, nutrients, trace elements, and metals' concentrations are listed in Table 1. Despite the extremely low conductivity $\left(9 \mu \mathrm{S} . \mathrm{cm}^{-1}\right)$, the water was only very-slightly acidic ( $\mathrm{pH}$ 6.2). Nutrient concentrations were very low, especially phosphorus (S.R.P. $3 \mu \mathrm{g} .1^{-1}$ ). Trace elements and metals were measured in parts per trillion. The only elements having notable concentrations were Al, Fe, U, Ti, Zn due to the lithological characteristics of the bedrock.

\section{Morphological Characterization}

The gametophyte thalli were small (up to $1 \mathrm{~cm} \mathrm{long),}$ olive green, primarily unbranched and in growing in dense tufts (Figs 2a,b). The base of the thalli are stalked and the spermatangia in rusty-brown discrete patches (Figs 2c,d). The thalli are pseudoparenchymatous, tubular, $150-500 \mu \mathrm{m}$ in diameter without the spermatangial papillae and $200-600 \mu \mathrm{m}$ in diameter with the spermatangial zones, with the surface covered in numerous hair cells (Figs 2e-g). Internodes 0.25 $0.35 \mathrm{~mm}$ long. In addition, the carposporophytes can be seen to project inwardly into the hollow centre (Figs $2 \mathrm{f}, \mathrm{g})$. The outer thallus is composed of small cells with several, parietal, disc-shaped chromoplast that can be easily seen in autofluorescence (Figs 2d,h,i). In crosssection, it is evident that much of the inner thallus is hollow with no cortical filaments filling the center and ray cells abutting the larger cells of the inside of the tube (Figs 2 f,g,j,k).

Both the qualitative and quantitative characteristics of the population were assessed and the most recent key to European Lemanea species consulted (ELORANTA et al. 2011). The diagnostic characteristics in the key showed the specimens to be Lemanea fluviatilis. However, the feature thallus height $(6-30 \mathrm{~cm}$ long) in the description was longer than the population study. Given that thallus length may vary considerably and all other characteristics were within the ranges provided, the population was assigned to Lemanea fluviatilis on the basis of morphology.

\section{Molecular data analysis}

An examination of sequence similarity showed that the sequence from this population was most closely related (99.1\%, similar or $11 \mathrm{bp}$ different) to a group of GenBank sequences (AY575163, AY575164, AY575167, AY575170). Both the BI and ML analyses produced trees with similar topologies such that only the BI tree with both the posterior probabilities and ML bootstrap values is shown (Fig. 3). The sequence from this study was sister to a clade containing sequences labelled as Lemanea fluviatilis (9), L. fucina (5) and Lemanea sp. (1) and its inclusion with the clade was well support (1.0/89). Like the sequence from the current study, all within this clade were collected from various European locations. L. borealis was shown to be sister to this clade but the support was low $(0.73 /-)$. In the current analysis, L. fluviatilis, L. fucina and L. borealis were all shown to be paraphyletic.

\section{Pigments and lipids}

The carotenoids profile of this alga contains significant amounts of $\alpha / \beta$-carotene, zeaxanthin and lutein - (Fig. 4a). Among chlorophylls (Fig. 4b), chlorophyll $a$ is dominant; the absence of chlorophyllide- $a$ (loss of phytyl chain, not detected) and the very low amount of phaeophytin- $a$ (loss of the magnesium ion, about 1\%)

Table 1. Physical and chemical characteristics of Chiese stream inhabited by Lemanea fluviatilis.

\begin{tabular}{|c|c|}
\hline Variable & Chiese Stream at Levade \\
\hline Temperature $\left({ }^{\circ} \mathrm{C}\right)$ & 5.9 \\
\hline Conductivity $\left(\mu \mathrm{S} . \mathrm{cm}^{-1}\right)$ & 9 \\
\hline $\mathrm{pH}$ & 6.2 \\
\hline $\mathrm{N}-\mathrm{NO}_{3}^{-}\left(\mu \mathrm{g} \cdot \mathrm{l}^{-1}\right)$ & 136 \\
\hline $\mathrm{N}-\mathrm{NH}_{4}^{+}\left(\mu \mathrm{g} \cdot \mathrm{l}^{-1}\right)$ & 9 \\
\hline $\mathrm{TN}\left(\mu \mathrm{g} \cdot 1^{-1}\right)$ & 219 \\
\hline $\mathrm{TP}\left(\mu \mathrm{g} .1^{-1}\right)$ & 6 \\
\hline S.R.P. $\left(\mu \mathrm{g} .1^{-1}\right)$ & 3 \\
\hline $\mathrm{SiO}_{2}\left(\mathrm{mg} \cdot \mathrm{l}^{-1}\right)$ & 2.4 \\
\hline $\mathrm{Na}^{+}\left(\mathrm{mg} . l^{-1}\right)$ & 0.70 \\
\hline $\mathrm{Ca}^{2+}\left(\mathrm{mg} . \mathrm{l}^{-1}\right)$ & 1.1 \\
\hline $\mathrm{Mg}^{2+}\left(\mathrm{mg} \cdot \mathrm{l}^{-1}\right)$ & 0.13 \\
\hline $\mathrm{SO}_{4}^{2-}\left(\mathrm{mg} . l^{-1}\right)$ & 0.6 \\
\hline $\mathrm{Cl}^{-}\left(\mathrm{mg} . \mathrm{l}^{-1}\right)$ & 0.2 \\
\hline $\mathrm{Al}\left(\mu \mathrm{g} .1^{-1}\right)$ & 58.08 \\
\hline $\mathrm{Ba}\left(\mu \mathrm{g} .1^{-1}\right)$ & 1.26 \\
\hline $\mathrm{Rb}\left(\mu \mathrm{g} \cdot 1^{-1}\right)$ & 1.90 \\
\hline $\mathrm{Cu}\left(\mu \mathrm{g} .1^{-1}\right)$ & 0.18 \\
\hline $\mathrm{Fe}\left(\mu \mathrm{g} \cdot 1^{-1}\right)$ & 51.79 \\
\hline $\operatorname{Mn}\left(\mu \mathrm{g} \cdot 1^{-1}\right)$ & 1.56 \\
\hline $\mathrm{Pb}\left(\mu \mathrm{g} \cdot 1^{-1}\right)$ & 0.06 \\
\hline $\mathrm{U}\left(\mu \mathrm{g} .1^{-1}\right)$ & 0.22 \\
\hline $\operatorname{Ti}\left(\mu \mathrm{g} .1^{-1}\right)$ & 11.82 \\
\hline $\operatorname{Sr}\left(\mu \mathrm{g} .1^{-1}\right)$ & 2.84 \\
\hline $\operatorname{Zn}\left(\mu \mathrm{g} .1^{-1}\right)$ & 11.74 \\
\hline $\operatorname{Mo}\left(\mu \mathrm{g} .1^{-1}\right)$ & 0.39 \\
\hline
\end{tabular}


determined in all the LC-UV chromatographic runs indicated both optimal storage conditions of the alga and mild extraction conditions.

Our LC-MS methodology also allowed identification of the membrane lipids contained in the raw extract of Lemanea fluviatilis (Table 2; Fig. 4c) relying on retention time on different chromatographic stationary phases (RP18 and HILIC), on full scan and tandem MS spectra obtained by positive and negative ESI ion-modes ionization. Among the structural components of chromoplast, we profiled 20 monogalactosyl diacylglycerols (MGDG), 22 digalactosyl diacylglycerols (DGDG) and 10 sulfoquinovosyl diacylglycerols (SQDG) with other cell membrane lipids were in the

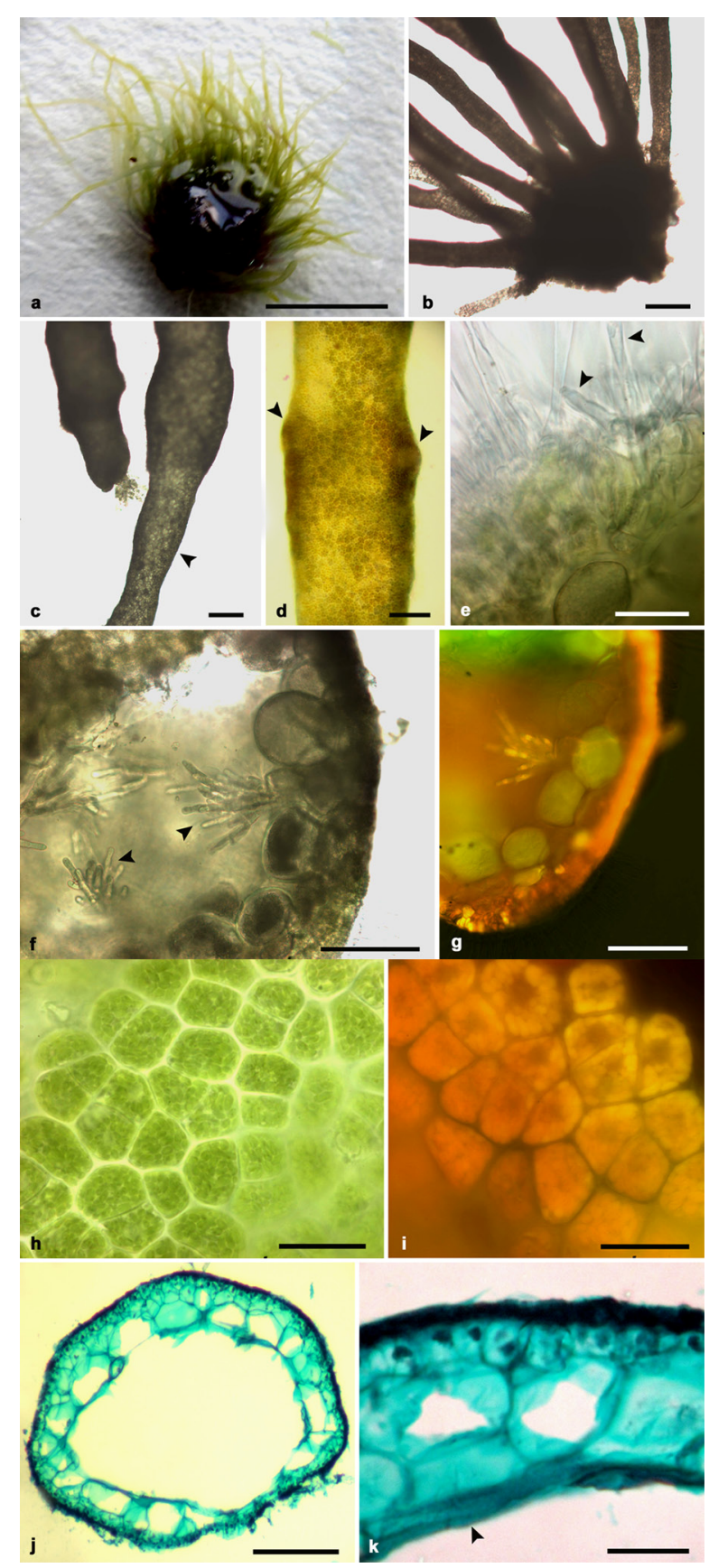

classes 3 diacylglyceryl N,N,N-trimethylhomoserine (DGTS) and 26 phospholipids belonging to the class of phosphaditylcholine (PC). Among galactolipids, MGDGs and DGDG bearing polyunsaturated and long fatty acyl chain (in particular EPA, the $\omega-3$ eicosapentaenoyl chain, 20:5) were the most abundant in this class (about 67\% and 52\%, respectively). Curiously, concerning plasma membrane lipids, this PUFA chain is very abundant (about $85 \%$ ) in PC lipid species and not present at all in any detectable DGTS species.

This hint is also in agreement with the averaged unsaturation index (UI) of each lipid class. The PUFArichest (PC and MGDG) are also the most unsaturated lipid classes (UI $=7.6$ and 6.8 respectively), followed by DGDG (4.1); the PUFA-poorest (SQDG and DGTS) are the less unsaturated lipid classes (UI $=3.3$ and 2.8 respectively).

As expected, a similar trend is found for the average chain length, with PC and MGDG having the highest ACL values (38.5 and 37.9 respectively), DGDG intermediate $(\mathrm{ACL}=35.9)$ whilst SGDG and DGTS have the lowest values (34.1 and 34.0).

\section{Discussion}

Most of the morphological characteristics examined would suggest that this Lemanea population belongs to the species Lemanea fluviatilis. However, the thalli collected in this study were distinctly short. The small stature of this population has been observed in other collections at the same site in different years (CANTONAтI personal observation). The small size may be due to the glacial mountain habitat as CANTONATI et al. (2001) collected similarly small thalli from the typical high discharge/high turbidity glacial Niscli Stream (Adamello) at an elevation of $2372 \mathrm{~m}$ a.s.1. (46 $06^{\circ} 50.25^{\prime \prime}$ $\mathrm{N}, 10^{\circ} 37^{\prime} 31.30^{\prime \prime} \mathrm{E}$ ). The smaller size of L. fluviatilis in this study might be an adaptive phenotypic mechanism to avoid the high current velocity and flow-related

Fig. 2. Morphological characteristics for the population of Lemanea fluviatilis: (a) overall habit showing small-sized olive-green unbranched thalli in dense clumps; (b) basal disc from which unbranched, pseudoparenchymatous thalli arise; (c) lower part of the thallus showing a short stalk (arrowhead); (d) magnified node showing spermatangia in rusty-brown patches (arrowhead); (e) close-up view of the thallus surface showing plentiful hair cells (arrowhead). (f) cross-section of thallus showing the developing carposporophyte with filaments (arrowhead) projecting into the center of the thallus; (g) autofluorescent plastids in the outer cortical cells, and carposporophyte filaments; (h) several, parietal, disc-shaped chromoplasts; (i) autofluorescent chromoplasts; (j) light green-stained transverse section showing a thin layer of small outer cortical cells, larger inner cortical cells with an empty central region; (k) magnification of the transverse section characterized by the small outer cortical cells and the larger inner cortical ones with ray cells (arrowhead) running parallel to the cortex. Scale bars $5 \mathrm{~mm}$ (a), $20 \mu \mathrm{m}(\mathrm{e}, \mathrm{h}-\mathrm{i}, \mathrm{k}), 200 \mu \mathrm{m}$ (b-d), $100 \mu \mathrm{m}(\mathrm{f}-\mathrm{g}, \mathrm{j})$. 


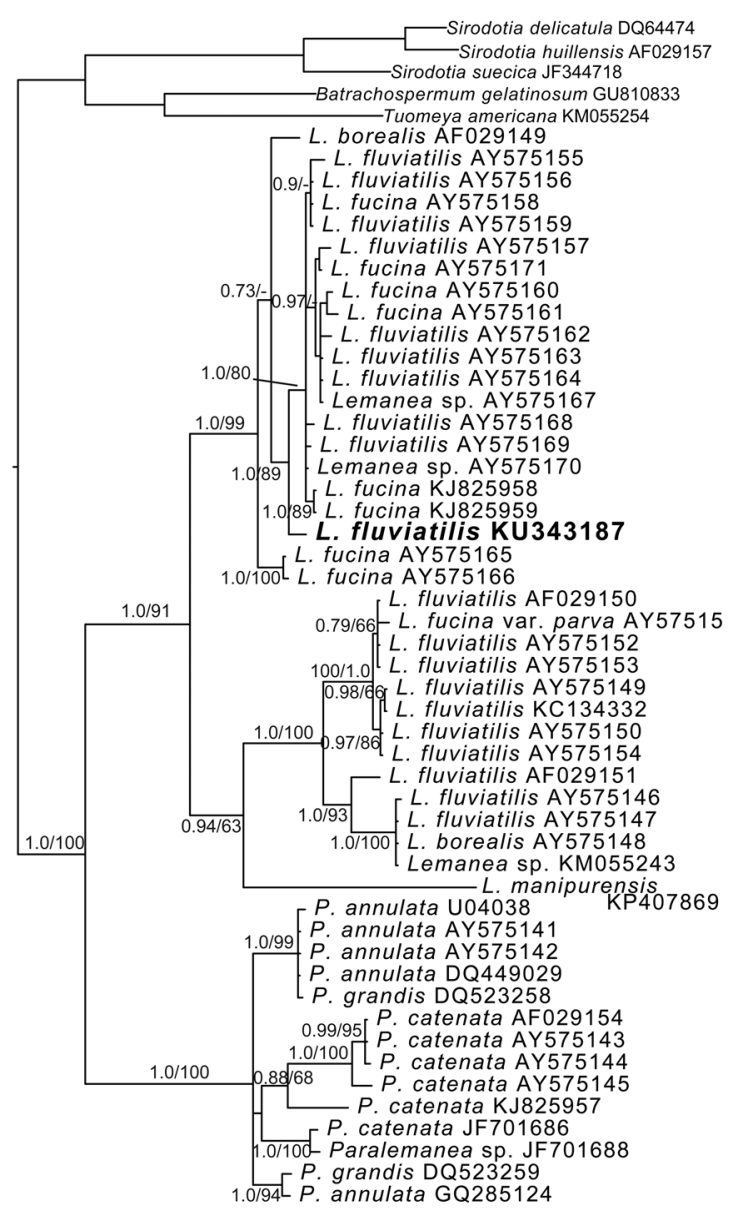

Fig. 3. Phylogenetic tree based on $r b c \mathrm{~L}$ sequence data showing the relationships of Lemanea fluviatilis (Italy) and previously published sequences from GenBank using Bayesian Inference analysis in Mr.Bayes v.3.2. Support values are shown as BI pp/ML bootstrap. Branches without values had $\mathrm{BI} p \mathrm{pp}<0.7$ and $\mathrm{ML}<60 \%$.

stress in the montane habitat in the south-eastern Alps. EveritT \& Burkholder (1991), Vis et al. (1991), EloRANTA \& KWANDRANS (1996) and FILKIN \& Vis (2004) in their studies of Lemanea and Paralemanea observed these taxa at high current velocity $\left(>1 \mathrm{~m} \cdot \mathrm{s}^{-1}\right)$, but with greater sized thalli. Perhaps, the smaller size is not related to current velocity, but the montane habitat (characterized, e.g., by scarce nutrient, in particular phosphorus availability). It likely seems that further studies are needed to assess how widespread the small sized thalli of L. fluviatilis are in high mountain populations of the Alps, and the possible adaptive significance of this feature.

The molecular data placed the Lemanea population from the current study as sister in a clade with sequences labelled as Lemanea fluviatilis, L. fucina and Lemanea sp. Unfortunately, there is no associated morphological data with the specimens from GenBank. Therefore, it is assumed that they were identified using the current circumscriptions for $L$. fluviatilis and $L$. fucina. These two taxa appear to be morphologically distinguished with L. fucina having many thalli bran- ched per population in VIS \& SHEATH (1992) and the stalk being more tapered as well as thalli not growing as compact tufts (ELORANTA et al. 2011; see Table S1). These morphological characters seem like they may be open to interpretation and could result in the species epithets being utilized differently. As well, there is the distinct possibility that these characteristics used for morphological identification may not be phylogenetically informative. Nevertheless, when future systematic studies are conducted, current Lemanea population will have both morphological and molecular data documented so that it can be easily included and may provide data from a more extreme montane habitat.

From the ecological standpoint, this study confirmed that L. fluviatilis prefers unpolluted, fast-flowing, oligotrophic, mountain streams with cold water. Accordingly, LeDERER \& SOUKuPOvÁ (2002) recorded this species in rocky mountain streams and rivers in Central Europe. VIs \& SheAth (1992) suggested that cold waters with an average temperature of $13{ }^{\circ} \mathrm{C}$ are the typical environments for members of the Lemaneaceae. They recorded populations in streams with water temperatures between 7 and $24^{\circ} \mathrm{C}$. KUČERA et al. (2008) showed that L. fluviatilis is a widespread species in Czech Republic, usually growing on boulders and cobbles in riffles, on weirs or in waterfalls which are partly-shaded or well-illuminated. They also confirmed that L. fluviatilis is not restricted to mountain streams, but occurs across an altitudinal gradient ranging from 305 to $888 \mathrm{~m}$ a.s.l. Accordingly, Eloranta \& KWANDRANS (1996) described this species from a wide range of flow velocity including strong currents (0.2-1.9 m.s $\left.{ }^{-1}\right)$. GutOwsKi et al. (2004), ElORANTA \& KwANDrans (2007), and CEschin et al. (2012) reported L. Aluviatilis from oligotrophic streams. VIS \& SHEATH (1992) reported that L. fluviatilis in North America occurs over a wide $\mathrm{pH}$ range (5.0-8.6). CESCHIN et al. (2012) determined this species in Italian watercourses with $\mathrm{pH}$ regimes ranging from neutral to alkaline (7.4-8.6).

One of the most notable features of our study site is the high elevation (2170 $\mathrm{m}$ a.s.l.). CANTONATI et al. (2001) sampled L. fluviatilis from a stream in the same mountain range at an elevation of $2372 \mathrm{~m}$ a.s.1. These reports might be some of the highest altitudes for Lemanea fluviatilis occurrence (compare e.g. SHEATH \& VIs 2015, who reported elevations up to $1200 \mathrm{~m}$ a.s.1.).

Recent studies of KwANDRANS \& Eloranta (2010) and ElORANTA et al. (2011) on freshwater red algae biodiversity in Italy lamented a scarcity of knowledge about the biogeographical patterns of this group in some Central European countries including Italy. Our record might contribute to a more detailed knowledge on the distribution of this species, particularly in regards to elevation and $\mathrm{pH}$. Recently, combined molecular /morphological studies have provided new insights into Lemanea/Paralemanea biodiversity in so far poorly studied geographic areas (GANESAN et 

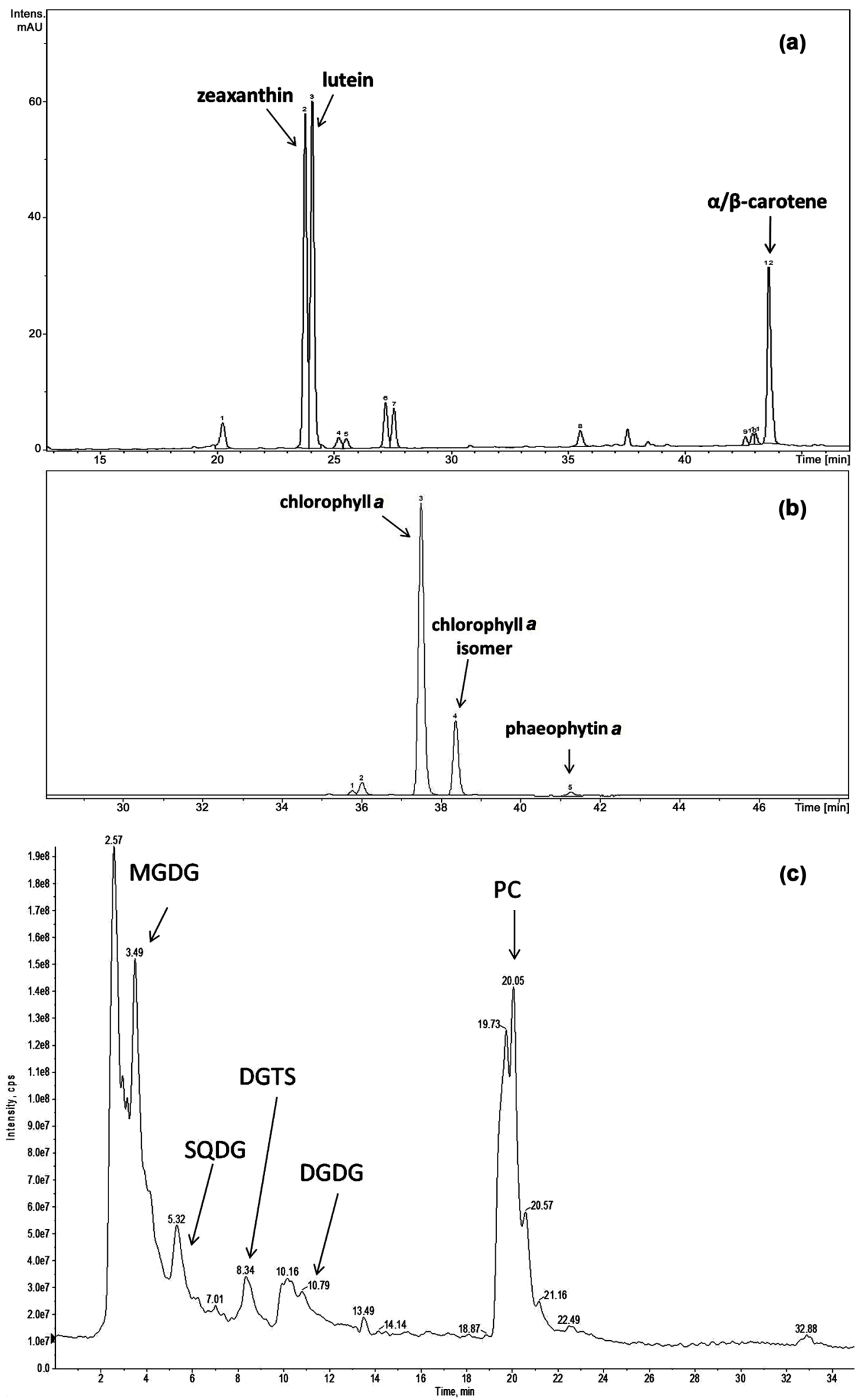

Fig. 4. Chromatograms of carotenoids, chlorophylls, and lipids for Lemanea fluviatilis: (a) RP8 chromatogram as detected by PDA at $1470 \mathrm{~nm}$ (carotenoids); (b) RP8 chromatogram as detected by PDA at $1665 \mathrm{~nm}$ (chlorophylls) (c) HILIC chromatogram as detected by full scan ESI(+) mass spectrometer (lipid classes). Intra-class lipid distribution was obtained in reversed-phase chromatographic conditions. 
Table 2. Results of the membrane lipidomics analysis of Lemanea fluviatilis detailed per lipid class.

\begin{tabular}{llllll}
\hline Items & \multicolumn{5}{c}{ Lipid classes } \\
& MGDG & DGDG & SQDG & PC & DGTS \\
\hline species & 20 & 22 & 10 & 26 & 3 \\
UI & 6.76 & 4.11 & 3.28 & 7.58 & 2.83 \\
ACL & 37.93 & 35.94 & 34.06 & 38.48 & 34 \\
\hline \multicolumn{2}{l}{$\begin{array}{l}\text { Total number of lipid molecu- } \\
\text { lar species }\end{array}$} \\
\hline
\end{tabular}

MGDG: monogalactosyl diacylglycerols; DGDG: digalactosyl diacylglycerols; SQDG: sulfoquinovosyl diacylglycerols; PC: phosphaditylcholine; DGTS: diacylglyceryl $N, N, N$-trimethylhomoserine; UI: the unsaturation index of each lipid class; ACL: average chain length for each lipid class.

\section{al. 2015).}

The carotenoids profile of this alga is in fair agreement with that expected for a macrophytic type Rhodophyta (Schubert \& García-Mendoza 2008). Moreover, this inventory of pigments, especially zeaxanthin and lutein, might have light-harvesting and protective functions in this harsh mountain habitat (TAKAICHI 2011).

Temperature and nutrient availability (specifically P) are the most influential environmental drivers affecting algal cell membrane fluidity and permeability by the presence of special algal membrane-lipids' classes, as an adaptive mechanism. DGTS are primitive lipids that are mainly determined in lower plants, algae, dinoflagellates, and mosses (KUMARI et al. 2013; RiEKHOF et al. 2014). They are structurally similar to PC, but lack the phosphate group. In general, DGTS lipids can completely replace PC lipids in the plasma membranes, especially in organisms living in harsh environments, like those with low or very low phosphorus availability. However, the average UI and ACL determined in this Lemanea fluviatilis population for these two lipid classes lie at opposite extremes, being the highest (UI $=7.6$ and $\mathrm{ACL}=38.5)$ for $\mathrm{PC}$ and the lowest (UI $=2.8$ and ACL $=34.0)$ for DGTS lipid species. Although, the L. fluviatilis habitat in our study has low phosphorus concentrations, nutrients in this turbulent, high-current-velocity habitat are likely to be replenished rapidly through the reduced boundary layer (MacFarlane \& Raven 1985; Sheath \& Hambrook 1990). Moreover, emerging evidence (GG unpublished data) seems to indicate that betaine lipids distribution mainly reflects the algal phylogenetic relationships rather than its ability to mediate changing environmental conditions.

The modifications of the unsaturation degree of the lipid acyl chains are important for maintaining adequate membrane fluidity and therefore all the metabolic processes associated to the plasma membrane, especially for organisms living in extreme environments. Accordingly, Lemanea fluviatilis living in lotic, very-cold streams possesses lipid species with high UI and long acyl chains. The detailed lipid analysis of this species further demonstrated that red algae are a rich source of a important $\omega-3$ fatty acids such EPA (20:5) as already been reported in the red alga Porphyridium cruentum (COHEN 1990) and in several other species.

\section{ACKNOWLEDGements}

We are grateful to Leonardo Cerasino, Edmund Mach Foundation, S. Michele all'Adige (TN, Italy) for making available main-ion \& nutrients data on the Lemanea habitat, and to Paolo Gabrielli and Emilie Beaudon, Byrd Polar and Climate Research Center, Columbus, OH USA, for providing trace elements' data. Emily Keil is thanked for sequencing the Lemanea specimen. The results of this study were presented at the International Workshop on Benthic Algae Taxonomy (InBAT), June $17^{\text {th }}-19^{\text {th }} 2015$, Museo delle Scienze - MUSE, Trento, Italy.

\section{REFERENCES}

Anesi, A. \& Guella, G. (2015): A fast liquid chromatography-mass Spectrometry methodology for membrane lipid profiling through hydrophilic interaction liquid chromatography. - Journal of Chromatography A 1384: 44-52.

APHA. (2000): Standard methods for the examination of water and wastewater, $20^{\text {th }}$ edition. American Public Health Association, Washington D.C.

Becker, S.; Graeve, M.K. \& Bischof, K. (2010): Photosynthesis and lipid composition of the Antarctic endemic rhodophyte Palmaria decipiens: effects of changing light and temperature levels. - Polar Biology 33: 945-955.

Cantonati, M.; Corradini, G.; Jüttner, I. \& Cox, E.J. (2001): Diatom assemblages in high mountain streams of the Alps and the Himalaya. - Nova Hedwigia, Beiheft 123: 37-62.

Cantonati, M.; Lange-Bertalot, H.; Decet, F. \& Gabrieli, J. (2011): Diatoms in very-shallow pools of the site of community importance Danta di Cadore Mires (south-eastern Alps), and the potential contribution of these habitats to diatom biodiversity conservation. - Nova Hedwigia 93: 475-507.

Carmona, J.; Perona, E.; SÁnchez-Díaz, E. \& Loza, V. (2011): Morphological and ecological characterization of Batrachospermales (Rhodophyta) in the Jarama Basin, Iberian Peninsula. - Limnetica 30: $117-128$.

Ceschin, S.; Bisceglie, S. \& Ricci, S. (2012): Contribution to the knowledge of red algae (Rhodophyta) of some rivers in Central Italy. - Cryptogamie Algologie 33: 61-67.

CoHen, Z. (1990): The production potential of eicosapentaenoic and arachidonic acids by the red alga Porphyridium cruentum. - Journal of the American Oil Chemists' Society 67: 916-920.

EdGAR, R.C. (2004): MUSCLE: a multiple sequence alignment method with reduced time and space complexity. - BMC Bioinformatics 5: 113.

Eloranta, P. \& Kwandrans, J. (1996). Distribution and ecology of freshwater red algae (Rhodophyta) in some Finnish rivers. - Nordic Journal of Botany 16: 107117. 
Eloranta, P. \& Kwandrans, J. (2007). Freshwater red algae (Rhodophyta). Identification guide to European taxa, particularly to those in Finland. - Norrlinia 15: $1-103$.

Eloranta, P.; Eloranta, A. \& Perämäki, P. (2016): Intensive study of Freshwater red algae (Rhodophyta) in Finland. - Fottea 16: $122-132$.

Eloranta, P.; Kwandrans, J. \& Kusel-Fetzmann, E. (2011): Rhodophyceae and Phaeophyceae. - In: SchagerL, M. (ed.): Süßwasserflora von Mitteleuropa, Band 7/ Freshwater Flora of Central Europe, Vol. 7. - pp. 1-155, Spectrum Akademischer Verlag, Heidelberg.

Entwisle, T.J.; VIs, M.L.; Chiasson, W.B.; NeCChI, O. JR. \& SHerwood, A.R. (2009): Systematics of the Batrachospermales (Rhodophyta) - a synthesis. - Journal of Phycology 45: 704-715.

Everitt, D.T. \& Burkholder, J.M. (1991): Seasonal dynamics of macrophyte communities from a stream flowing over granite flatrock in North Carolina, USA. Hydrobiologia 222: 159-172.

Filkin, N.R. \& VIS, M.L. (2004): Phenology of Paralemanea annulata (Lemaneaceae, Rhodophyta) in an Ohio woodland stream. - Hydrobiologia 518: 159-168.

Flaim, G.; Obertegger, U. \& Guella, G. (2012): Changes in galactolipid composition of the cold freshwater dinoflagellates Borghiella dodgei in response to temperature. - Hydrobiologia 698: 285-293.

Folch, J.; Lees, M. \& Sloane Stanley, G.H. (1957): A simple method for the isolation and purification of total lipids from animal tissues. - Journal of Biological Chemistry 226: 497-509.

Frassanito, R.; Cantonati, M.; Tardìo, M.; Mancini, I. \& Guella, G. (2005): On-line identification of secondary metabolites in freshwater microalgae and cyanobacteria by combined liquid chromatographyphotodiode array detection-mass spectrometric techniques. - Journal of Chromatography A 1082: 33-42.

Fuschino, J.R.; Guschina, I.A.; Dobson, G.; Yan, N.D.; Harwood, J.L. \& ARTS, M.T. (2011): Rising water temperatures alter lipid dynamics and reduce n-3 essential fatty acid concentrations in Scenedesmus obliquus (Chlorophyta). - Journal of Phycology 47: 763-774.

Ganesan, E.K.; West, J.A.; Zuccarello, G.C.; Loiseaux de GoËr, S. \& Rout, J. (2015): Lemanea manipurensis sp. nov. (Batrachospermales), a freshwater red algal species from North-East India. - Algae 30: 1-13.

Guella, G.; Frassanito, R. \& Mancini, I. (2003): A new solution for an old problem: the regiochemical distribution of the acyl chains in galactolipids can be established by electrospray ionization tandem mass spectrometry. - Rapid Communications in Mass Spectrometry 17: 1982-1994.

Guindon, S. \& Gascuel, O. (2003). A simple, fast, and accurate algorithm to estimate large phylogenies by maximum likelihood. - Systematic Biology 52: 696-704.

Gutowski, A.; Foerster, J. \& Schaumburg, J. (2004): The use of benthic algae, excluding diatoms and Charales, for the assessment of the ecological status of running fresh waters: a case history from Germany. - Oceanological and Hydrobiological Studies 33: 3-15.

Harding, J.P.C. \& Whitton, B.A. (1981): Accumulation of zinc, cadmium and lead by field populations of Lemanea. - Water Research 15: 301-319.
Kearse, M.; Moir, R.; Wilson, A.; Stones-Havas, S.; Cheung, M.; Sturrock, S.; Buxton, S.; Cooper, A.; Markowitz, S.; Duran, C.; Thierer, T.; Ashton, B.; Mentjes, P. \& Drummond, A. (2012): Geneious Basic: an integrated and extendable desktop software platform for the organization and analysis of sequence data. - Bioinformatics 28: 1647-1649.

Keil, E.J.; Macy, T.R.; Kwandrans, J.; Eloranta, P.; Tomas, P.; AвoAl, M. \& VIs, M.L. (2015): Phylogeography of Batrachospermum gelatinosum (Batrachospermales, Rhodophyta) shows post-glacial expansion in Europe. - Phycologia 54: 176-182.

KuČera, P.; Grulich, V.; FránKová, M. \& Bureš, P. (2008): Distribution of freshwater red algal family Lemaneaceae (Rhodophyta) in the Czech Republic: an update. - Fottea 8: 125-128.

Kumari, P.; Kumar, M.; Reddy, C.R.K. \& Jha, B. (2013): Algal lipids, fatty acids and sterols. - In: DomingueZ, H. (ed.): Functional ingredients from algae for foods and nutraceuticals. - pp. 87-134, Woodhead Publishing Limited, Oxford.

KwandRans, J. \& Eloranta, P. (2010): Diversity of freshwater red algae in Europe. - Oceanological and Hydrobiological Studies 39: 161-169.

Leblond, J.D.; Khadka, M.; Duong, L. \& Dahmen, J.L. (2015): Squishy lipids: Temperature effects on the betaine and galactolipid profiles of a $\mathrm{C}_{18} / \mathrm{C}_{18}$ peridinin-containing dinoflagellate, Symbiodinium microadriaticum (Dinophyceae), isolated from the mangrove jellyfish, Cassiopea xamachana. - Phycological Research 63: 219-230.

LEDERER, F. \& SOUKuPOVÁ, L. (2002): Biodiversity and ecology of algae in mountain bogs (Bohemian Forest, Central Europe). - Algological Studies 106: 151183.

MacFarlane, J.J. \& Raven, J.A. (1985): External and internal $\mathrm{CO}_{2}$ transport in Lemanea: interactions with the kinetics of ribulose bisphosphate carboxylase. Journal of Experimental Botany 36: 610-622.

NeCCHI JR., O. (1997): Microhabitat and plant structure of Batrachospermum (Batrachospermales, Rhodophyta) populations in four streams of São Paulo State, Southeastern Brazil. - Phycological Research 45: $39-45$.

Pipp, E. \& Rotт, E. (1994): Classification of running-water sites in Austria based on benthic algal community structure. - Verhandlungen Internationale Vereinigung für Theoretische und Angewandte Limnologie 25: $1610-1613$

Riekhof, W.R.; Naik, S.; Bertrand, H.; Benning, C. \& VoelKer, D.R. (2014): Phosphate starvation in fungi induces the replacement of phosphatidylcholine with the phosphorus-free betaine lipid diacylglyceryl$N, N, N$-trimethylhomoserine. - Eukaryotic Cell 13: $749-757$.

Ronquist, F.; Teslenko, M.; van der Mark, P.; Ayres, D.L.; Darling, A.; HöHna, S.; Larget, B.; Liu, L.; SuchaRD, M.A. \& HuelsenBeCK, J.P. (2012): MrBayes 3.2: efficient Bayesian phylogenetic inference and model choice across a large model space. - Systematic Biology 61: 539-542.

RotT, E. \& SchneIDER, S.C. (2014): A comparison of ecological optima of soft-bodied benthic algae in Norwegian and Austrian rivers and consequences for river monitoring in Europe. - Science of the Total 
Environment 475: 180-186.

Rott, E.; VAn Dam, H.; Pfister, P.; PIPP, E.; Pall, K.; BinDER, N. \&ORTLER, K. (1999): Indikationslisten für Aufwuchsalgen. - Teil 2: Trophieindikation, geochemische Reaktion, toxikologische und taxonomische Anmerkungen. Publ. Wasserwirtschaftskataster, BMfLF: $1-248$.

Schubert, N. \& García-Mendoza, E. (2008): Photoinhibition in red algal species with different carotenoid profiles. - Journal of Phycology 44: 1437-1446.

Sheath, R.G. \& Hambrook, J.A. (1990): Freshwater Ecology. - In: Cole, K.M. \& Sheath, R.G. (eds): Biology of the Red Algae. - pp. 423-453, Cambridge University Press, Cambridge.

SheAth, R.G. and Sherwood, A.R. (2011): Rhodophyta (Red Algae). - In: John, D.M.; Whitton, B.A. \& Brook, A.J. (eds): The freshwater Algal Flora of the British Isles: An identification guide to freshwater and terrestrial algae, $2^{\text {nd }}$ edition. - pp. 159-180, Cambridge University Press, Cambridge.

SheAth, R.G. and Vis, M.L. (2015): Red algae. - In: WeHr, J.D.; Sheath, R.G. \& Kociolek, J.P. (eds): Freshwater Algae of North America: Ecology and Classification, $2^{\text {nd }}$ edition. - pp. 237-264, Academic Press, San Diego.

TAKAICHI, S. (2011): Carotenoids in algae: distributions, biosyntheses and functions. Marine Drugs 9: 1101-1118.

Thrib, H.H. \& Benson-Evans, K. (1982): The effect of different current velocities on the red alga Lemanea in a laboratory stream. - Archiv für Hydrobiologie 96: $65-72$.
Thrib, H.H. \& Benson-Evans, K. (1984): The effect of temperature on the growth of Lemanea thalli and carpospore germination. - Archiv für Hydrobiologie 103: 341-346.

Thrib, H.H. \& Benson-Evans, K. (1985): The effect of water temperature, current velocity and suspended solids on the distribution, growth and seasonality of Lemanea fluviatilis (C. Ag.), Rhodophyta, in the River Usk and other South Wales rivers. - Hydrobiologia 127: 63-78.

Vis, M.L. \& Sheath, R.G. (1992): Systematics of the freshwater red algal family Lemaneaceae in North America. - Phycologia 31: 164-179.

Vis, M.L.; Carlson, T.A. \& Sheath, R.G., (1991): Phenology of Lemanea fucina (Rhodophyta) in a Rhode Island river USA. - Hydrobiologia 222: 141-146.

VIS, M.L.; Harper, J.T. \& SAunders, G.W. (2007): Large subunit rDNA and $r b c L$ gene sequence data place Petrohua bernabei gen. et sp. nov. in the Batrachospermales (Rhodophyta), but do not provide further resolution among taxa in this order. - Phycological Research 55: 103-112.

Vis, M.L.; Saunders, G.W.; Sheath, R.G.; Dunse, K. \& EnTwisle, T.J. (1998): Phylogeny of the Batrachospermales (Rhodophyta) as inferred from $r b c \mathrm{~L}$ and $18 \mathrm{~S}$ ribosomal RNA gene DNA sequences. - Journal of Phycology 34: 341-350.

XIE, S. -L.; SHI, Z. -X. \& WANG, R. -N. (2004): Taxonomy of the Lemaneaceae (Batrachospermales, Rhodophyta) in China. - Acta Botanica Sinica 46: 883-888.

Supplementary material

the following supplementary material is available for this article:

Table S1. Morphometrical and ecological comparative study between L. fluviatilis and L. fucina in this study and other relevant literature.

Excel file. Details of lipidomics and pigments of L. fluviatilis in this study.

This material is available as part of the online article (http://fottea.czechphycology.cz/contents)

(C) Czech Phycological Society (2016)

Received January 2, 2016

Accepted April 18, 2016 